\title{
Research Article \\ Solid Waste Generation and Management Practice in Pokhara
}

\author{
Sarmila Bhattarai \\ Freelancer Researcher \\ Correspondingemail: bsarmila53@gmail.com
}

Article History

Received 29 April 2021

Revised 27 November 2021

Accepted 23 November 2021

\begin{abstract}
This study aimed to identify the current status of solid waste generation and its management in Pokhara. For this purpose, eleven institutions were chosen from all the 33 wards of Pokhara Metropolitan City for collecting the information regarding waste generation and composition. Further focus group discussions were carried out with five private sectors involved in the solid waste management system of Pokhara. The per capita waste generation rate was found to vary from minimum value $0.016 \mathrm{~kg}$ and to a maximum value of $0.082 \mathrm{~kg}$. along with the average of $0.035 \mathrm{~kg}$. The analysis of waste composition showed that landfill matter accounted for the highest fraction, making up $39.23 \%$ of landfill waste, $35.14 \%$ of reusable/recycle waste and $25.63 \%$ of organic waste. The challenges of solid waste management are increment of waste generations as well as per capita generation with respect to population growth and catchment area, scarcity of garbage collection vehicle, very difficult to manage dead animals, lack of proper management of medical and Industrial waste and hazards waste, health problem of solid waste management staff. The results can be used as part of the waste management planning purpose for the concerned stakeholders.
\end{abstract}

Keywords: Composition, landfill, organic, population growth, reusable, solid waste generation

\section{INTRODUCTION}

The definitions are transparent to allow for country-specific modifications, as waste categorization varies much from country to country, and can encompass different waste

(C) The Author, published by JRCC, Janapriya Multiple Campus. 
components. If the available data used in the inventory cover only certain waste types or sources (e.g., municipal waste), this limited availability should be documented clearly in the inventory report and efforts should be made to complement the data to cover all waste types (IPCC, 2016). Solid waste management is an essential service in any society. Before introducing the process, however, let's start with a discussion of the material being managedsolid waste.

Public sector inefficiencies and continuously increasing cost has led local authoritiesto analyze if this service can better be provided by the private sector (Massoud \& El-Fadel, 2002). Increasingly public-privatepartnerships (PPP) have emerged as an alternative to improve municipal solid waste service performance at lower costs (Cointreau et al. 2000; Zhu et al., 2007; Abdrabo, 2008). Solid waste should be managed through a number of activities — waste prevention, recycling, composting, controlled burning, or land filling. Using a combination of these activities together in a way that best protects your community and the local environment is referred to as integrated solid waste management (Lohri et al., 2014).

The household waste generation rates varied depending on caste and ethnicity, the analysis of waste generation shows that the highest per capita generation making up $0.4 \mathrm{~kg}$ produced by Dalit, $0.33 \mathrm{~kg}$ produced by Janajati and $0.31 \mathrm{~kg}$ produced by Brahmin/Chhetri. The analysis of waste composition showed that organic matter accounted for the highest fraction, making up $64.47 \%$ of organic waste, $14.57 \%$ of reusable/recycle waste and 20.69 of landfill (Bhattarai et al., 2019).

By waste type, the organic waste accounted for higher share compared to the inorganic and other wastes. The organic waste composition was highest (54.0\%) in 2075/76 compared to the inorganic waste (33.3\%) and other wastes (12.7\%). The municipal waste is generated from varied sources such as households, institutions, business/commercial Executive Summary complex, hospitals, etc. Among the metropolitan cities, the quantity of daily waste collection was highest in the household (15900 kg/day), followed by business complex (7700 kg/day) and the educational institutes $(4680 \mathrm{~kg} / \mathrm{day})$. Similarly, the households remained the major sources of waste generation in the sub-metropolitan cities (3300 kg/day) and municipalities (1440 kg/day) (CBS, 2020).

Municipal waste is everything collected and managed further by municipalities. Only part of it is comes from households, the rest is generated by small businesses, commercial and other municipal activities. Therefore, it is produced from both consumption and production processes. Like all wastes, municipal waste is on the rise and it is growing faster than the 
population, a natural result of our increasing consumption rate and the shortening of product life-spans (SWM Act, 2011). It is necessary to quantify the amount of waste generated as well as the current solid waste management practice so as to identify the problem and future prospects. In this context, this study aimed to identify the current status of solid waste generation and its management in Pokhara.

\section{DATA AND METHODS}

Pokhara Metropolitan City was chosen as the study area because the generation of municipal solid waste is being observed to be increased day by day and with together migration and floating population is very high and rapid. From 33 wards of Pokhara Metropolitan City (PMC), eleven institutions were chosen purposively for this study. The following procedure was carried out for the selection of the sample:

- Total of eleven institutions for survey were selected on the basis of pre- determined criteria.

- Sample institutions' owner were trained and oriented about the survey and their role.

- Three different colored waste collecting buckets for three different types of wastes (composting-green, reusing/recycle-blue and landfill-red) were distributed to the entire sample institutions. Separate poly bags were distributed to the single institutions comprising of different stakeholders.

- Surveyors observed the collected wastes in three different buckets and weighed separately, three days regularly.

- Weight of separate wastes was recorded in predefined data sheet.

- Total weight of three different types of waste was also recorded.

- Analysis of collected data was conducted.

Team of trained surveyors and the researcher visited the sample institution for survey and filled the data in field. For the case of composition of waste, team of trained surveyors including selected monitors visited the sample institution for survey and filled up the measurement data format in pre -defined data sheet with three broad types of wastes (Composting, Recycle/Reuse and Landfill) in field. Again for collection system, weight of collected waste was taken by the waste collecting vehicles of municipal as well as private sector. Whole process was monitored by monitoring individually and Mayor/Chief Executive officer of the Municipality. Focus Group Discussions (FGDs) werecarried out with five private sectors related to the MSW in PMC on Jan 3, 2018. Key informant interview (KII) was carried out among the stakeholders of PMC on Jan 4, 2018. 


\section{RESULTS AND DISCUSSION}

\section{Institution (Schools) Waste Generation}

The per capita waste generation of Schools was calculated by dividing the total waste produced by the number of students living in that school on that day. The sample size of 11 schools from 33 wards is considered for this analysis. The average school's waste generation as well per capita waste generation with respect to students number of each school. The table shows that the per capita waste generation rate was found to vary from minimum value 0.016 $\mathrm{kg}$ and to a maximum value of $0.082 \mathrm{~kg}$.

\section{Table1}

Distribution of per Capita Waste Generation from Schools in Different Wards in PMC

\begin{tabular}{|c|c|c|c|c|c|c|}
\hline \multirow{2}{*}{$\begin{array}{l}\text { Sample } \\
\text { No. }\end{array}$} & \multicolumn{3}{|c|}{ Total Weight (Kg) } & \multirow{2}{*}{$\begin{array}{l}\text { Average } \\
\text { Wt. }(\mathrm{Kg})\end{array}$} & \multirow{2}{*}{$\begin{array}{l}\text { No. of } \\
\text { Student }\end{array}$} & \multirow{2}{*}{$\begin{array}{l}\text { Per capita } \\
\text { Generation/day }\end{array}$} \\
\hline & Day 1 & Day 2 & Day 3 & & & \\
\hline 1 & 35.9 & 27.9 & 27.9 & 30.57 & 1100 & 0.028 \\
\hline 2 & 35.9 & 27.9 & 31.6 & 31.80 & 2000 & 0.016 \\
\hline 3 & 29.9 & 33 & 21 & 27.97 & 1300 & 0.022 \\
\hline 4 & 40 & 46.3 & 44.5 & 43.60 & 860 & 0.051 \\
\hline 5 & 16.9 & 19.3 & 13.6 & 16.60 & 750 & 0.022 \\
\hline 6 & 23.8 & 22.9 & 35 & 27.23 & 1085 & 0.025 \\
\hline 7 & 44.1 & 38.7 & 15 & 32.60 & 1580 & 0.021 \\
\hline 8 & 40 & 31.3 & 26.5 & 32.60 & 1150 & 0.028 \\
\hline 9 & 31.7 & 26.1 & 27.7 & 28.50 & 680 & 0.042 \\
\hline 10 & 27.6 & 19.3 & 20 & 22.30 & 1050 & 0.021 \\
\hline 11 & 53.8 & 38.9 & 46.3 & 46.33 & 1150 & 0.040 \\
\hline \multicolumn{6}{|c|}{ Average percapita Generation/day } & 0.035 \\
\hline
\end{tabular}

Source: Field Survey, 2017

\section{Composition of School (Institutional) Waste}

Waste generated from schools was categorized as institutional waste. The composition analysis revealed $35.14 \%$ paper and paper products (Reused), 25.63\% Food waste/organic (Composting wastes), 39.23\% plastic, textiles, metals, and rubber and leather (Land Fill waste). The higher fraction of paper and paper products and plastics came from students' snack boxes and discarded white paper. A relatively low level of organic waste is generated in schools because little fresh food is handled. 


\section{Figure 1}

Distribution of Composition of Institutional Waste

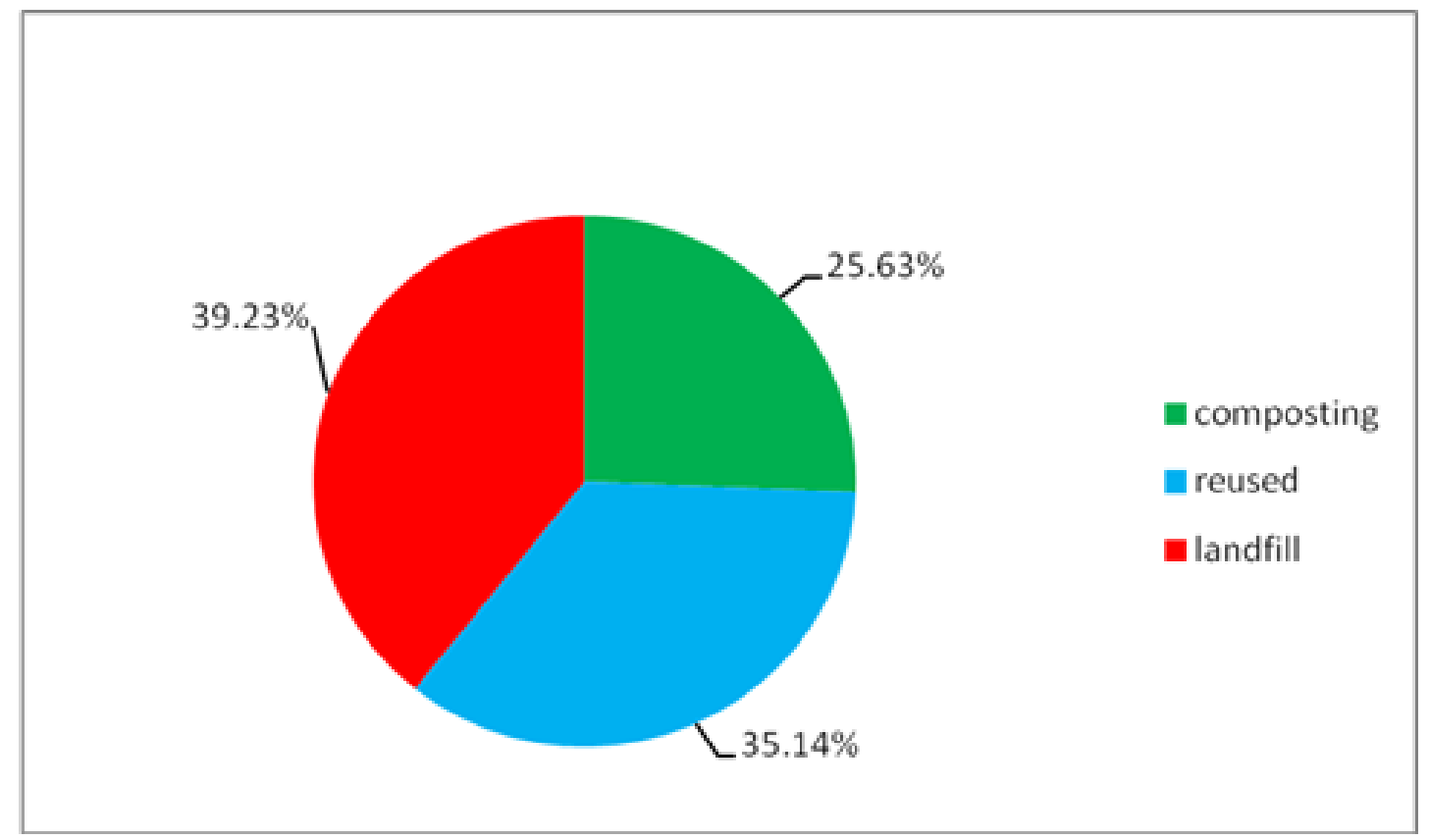

Source: Field Survey, 2017

\section{Challenges of SWM in PMC}

There have been numerous debates about population growth in many cities of developing countries. Solid waste management is a challenge for the cities' authorities in developing countries mainly due to the increasing generation of waste, the burden posed on the municipal budget as a result of the high costs associated to its management, the lack of understanding over a diversity of factors that affect the different stages of waste management and linkages necessary to enable the entire handling system functioning. The Key challenges of solid waste management in PMC are increment of waste generations as well as per capita generation with respect to population growth and catchment area of PMC, scarcity of garbage collection vehicle and extensive catchment area of PMC, very difficult to manage dead animals, lack of proper management of medical and Industrial waste and Hazards waste, health problem of SWM staff.

\section{Support from the Municipality to Private Sectors}

According to the private sectors, Municipality has given the opportunity to serve in MSW that 
is the main support from the government sector. Some private sector still uses the municipal vehicle to collect the garbage and most important support to provide landfill site for final waste disposal. In Nepalese context, it is very difficult or nearly impossible to get their (private sector) own landfill site for the garbage disposal. PMC has also given the rights to collect revenue from the households on the basis of rated that approved by annual municipal council. They have got $80 \%$ amount from the municipality out of total revenue collection.

\section{Problem Faced by Private Sector}

Most of the private sectors have been facing great problem in revenue collection in core area of the city rather than the other area, whereas more amount of revenue holds in main city area. Likewise, they are facing very short-term working permit agreement due to this reason; they hesitate to invest in this field with the fair of termination.

From the information through discussion, most of the participants are involved in waste management as well as other occupation. Some of them have more experience in the MSW management but some are starting recently in this field. Some of private sectors seem very happy to serve in MSW. All of the private operators agreed that the public i.e. household owner are little bit benefitted by their service rather than the municipal services due to providing the waste collection (door to door waste collection) vehicle frequently.

Further, from KII taken with the key person related to the MSW in PMC on Jan 4, 2018 in the office of PMC, it reveals that Pokhara Lekhnath Metropolitan City i.e. (Local Government) is the main responsible institution for the municipal solid waste management. There was an interview organized with some responsible staff those involve in the SWM as a key informant (Key person). According to the interview, PMC has prepared certain schedule ward wise and five private sectors have given task to collect the waste from their wards. Main city areas are cleaned by municipal staffs and collected waste transported by the private sector to the landfill site. For some wards municipal it provides the service to collect the waste. There was some serious problem in MSWM according to the key informant. Among them, main problem is generation of waste increasing day by day with respect to population growth and similarly catchment area for SWM.

\section{CONCLUSION}

The per capita waste generation rate was found to vary from minimum value $0.016 \mathrm{~kg}$ and to a maximum value of $0.082 \mathrm{~kg}$. along with the average of $0.035 \mathrm{~kg}$. The analysis of waste 
composition showed that landfill matter accounted for the highest fraction, making up 39.23 $\%$ of landfill waste, $35.14 \%$ of reusable/recycle waste and $25.63 \%$ of organic waste. Private sectors have been facing great problem in revenue collection in core area of the city rather than the other area, whereas more amount of revenue holds in main city area. They are facing very short-term working permit agreement due to this reason; they hesitate to invest in this field with the fear of termination. Other challenges of solid waste management are increment of waste generations as well as per capita generation with respect to population growth and catchment area of PMC, scarcity of garbage collection vehicle, very difficult to manage dead animals, lack of proper management of medical and Industrial waste and hazards waste, health problem of SWM staff.

\section{REFERENCES}

Abdrabo, M. A. (2008). Assessment of economic viability of solid waste service provision in small settlements in developing countries: A case study Rosetta, Egypt. Waste Management, 28 (12), 2503-2511.

Bhattarai, S., Kunwar, L.S., and Dhungana, A. R. (2019). Household solid waste generation and composition in Pokhara. Journal of Interdisciplinary Studies, 8, 79-87.

CBS, (2020). Waste management baseline survey of Nepal. Central Bureau of Statistics.

Cointreau, S., Gopalan, P., \& Coad, A. (2000). Private sector participation in municipal solid waste management: Guidance pack (5 Volumes). SKAT, St. Gallen, Switzerland.

DA Zhu, D., Asnani, P.U., Zurbrugg, C., Anapolsky, S., \& Mani, S. (2007). Improving solid waste management in India: A sourcebook for policy makers and practitioners. The World Bank, Washington, DC.

Lohri, C. R., Camenzind, E. J., \& Zurbrügg, C. (2014). Financial sustainability in municipal solid waste management: Costs and revenues in Bahir Dar, Ethiopia. Waste Management, $34,542-552$.

Massoud, M., El-Fadel, M. (2002). Public-private partnerships for solid waste management services. Environmental Management, 30 (5), 621-630.

GoN (2011). Solid waste management Act, 2011. Government of Nepal.

IPCC (2006). Guidelines for national greenhouse gas inventories Volume 5. Task Force on National Greenhouse gas Inventories.

Leblanc, R. (2020). An introduction to solid waste management, Retrieved from https://www. thebalancesmb.com/an-introduction-to-solid-waste-management-2878102 